\title{
Analysis of the Effect of Asset Allocation on Portfolio Performance with Diversification as an Intervening Variable
}

\author{
Dipa Teruna Awaludin ${ }^{1}$, Hasanudin ${ }^{2}$, Faysal Deni Rahman ${ }^{3}$ \\ 1,2,3 Universitas Nasional, Jakarta, Indonesia \\ Email: dipateruna@civitas.unas.ac.id
}

\begin{abstract}
This study aims to analyze the effect of asset allocation on portfolio performance with diversification as an intervening variable in the Pension Fund, a non-bank financial institution that manages the pension program and is registered and supervised by the Financial Services Authority (OJK) in the 2016-2019 period. A total of 34 Pension Funds were sampled so that the total sample was 136 in the 2016-2019 period. Data analysis using Structural Equation Modeling (SEM). The results showed that Selection Ability and Fund Size had a significant effect on Diversification, while Timing Ability had a significant effect on Portfolio Performance. Intervening test using Sobel Test shows that Diversification has not been able to mediate Asset Allocation on Portfolio Performance.
\end{abstract}

Keywords: Asset Allocation, Diversification, Portfolio Performance, Pension Fund.

\section{A. INTRODUCTION}

The outbreak of the Covid-19 pandemic has resulted in instability and shocks that have led to a downward trend in the economic sector, both on a global and national scale. This can be seen from various businesses in the world, including the investment world. The outbreak of the COVID-19 pandemic that entered Indonesia in early 2020 dealt a major blow to the Indonesian economy in almost all sectors. The uncertainty resulting from the Covid-19 pandemic has made us aware of the importance of how to prepare for the future, by allocating the right assets to be used at the right time (low risk with optimal return).

However, in the midst of the spread of the Covid-19 pandemic, something interesting happened in Indonesia, in June 2020 the Financial Services Authority said that pension fund investment grew by 3.33\% year on year, which was Rp. 282.74 trillion. This trend is expected to be a good capital to welcome the new normal era. It was further explained that the majority of pension funds play it safe by investing more of their funds in the type of fixed income so that it is safe and low risk. Therefore, OJK estimates that the previously projected rate of return cannot be fully met.

According to OJK data, the number of Pension Fund actors as of September 2020 is 216, this value tends to shrink from the previous year where in September 2019, there were 225 registered Pension Fund players, but this does not apply to the amount of investment that occurred. In September 2019 Pension Fund investment was only 274,615 billion rupiah, and in September 2020, Pension Fund investment increased to 284,026 billion rupiah.

During the January to September 2020 period, Pension Fund players allocate more of their investment in Time Deposits, SBN, Corporate Bonds, stocks and Mutual 
Funds. While the weight of the allocation made to Direct Investment, Land and or Buildings is small. Interestingly, until the end of September 2020, data on Debt on Pension Benefits and Other Benefits that have been due only amounted to 248.22 billion rupiah, or $0.087 \%$ of the total investment in the same period, then why did Pension Fund actors put $28.5 \%$ of their investment in Time Deposits, and only put $8.55 \%$ in the combined investment of Direct Investment, Land, Building, and Land and Building, this also happened YoY (year on year) previously.

\section{B. LITERATURE REVIEW}

\section{Investment Theory}

According to Tandellin (2001), investment is seriousness in allocating large amounts of resources today to obtain future profits. Currently, investment is described through various activities, ranging from investing in real assets (gold, land and/or buildings, machinery) or financial assets (bonds, stocks, warrants, options, futures, deposits, etc.).

The main purpose of investors investing is to get some profit and increase their welfare. Investors do not always have to have wealth first to invest, besides investors can use their assets or loans from other parties. There are considerations that make an appropriate investment very important:

a. In order to have a better life

b. The threat of inflation

c. Tax saving

The source of investment benefits is generated through yield/income and capital gains. Yield / income is the benefit of investments that are given regularly and periodically. While capital gains come from an increase that provides a profit on a securities (stocks or bonds) or in short capital gains are an increase in the price of securities that provide benefits. Systematically the total return is described by the formula: Return = yield + capital gain (loss).

Risk is closely related to return, an investor must always calculate the level of risk as a basis for making policy. Risk is a concern about the difference that arises between the difference in expected returns and what is actually received. The greater the potential return, in general, the riskier the investment. Sources of risk in an investment can be influenced by several factors, including: inflation risk, market, interest rate, business conditions, currency exchange, liquidity, including state risk.

In the concept of portfolio management, there is a theory to reduce risk by adding a number of securities to the portfolio composition. This theory becomes an important concept for understanding the spread of risk of a portfolio which creates a reduction in potential risk by increasing the number of different securities in the portfolio. This theory is the same as the law of large number theory in statistics, the larger the sample population, the greater the possibility of the sample to approach the expected value. The risk reduction mechanism in the portfolio is in principle the same as insurance, where as many insurance policies as possible can reduce risk. 


\section{Pension Fund}

In Indonesia, the management of pension funds is formed in the model of a legal entity type of Pension Fund. Pension Funds were first regulated through Law No. 11 of 1992 which regulates general provisions regarding pension funds, requirements for formation as well as the objectives and direction of program implementation, which then appeared derivative rules such as Government Regulations (PP); PP 76/1992, PP 77/1992, Regulation of the Minister of Finance (PMK); PMK 199/2008, PMK 19/2012, Regulation of the Financial Services Authority (POJK); POJK 3/2015, POJK 13/2016, POJK 14/2016 and also includes circulars issued from the Financial Services Authority.

Furthermore, Pension Funds are classified into two groups, namely: Employer Pension Funds (DPPK), which are established in the form of legal entities, which can be formed by individuals or other legal entities to administer pension programs for the benefit of the community. Then, the Financial Institution Pension Fund (DPLK), is established in an entity in the form of a legal entity, which is formed by a banking financial institution and/or life insurance company, which provides a pension program for the community and is separate from the DPPK of their own employees.

\section{Diversification Theory}

Diversification aims to form an optimal portfolio with the aim of without reducing the expected return in the slightest, through the mechanism of selecting certain assets in such a way that the possibility of each risk can be minimized. The next problem in diversifying is the process of determining the specific assets to be selected and determining the ideal size to invest in the portfolio. Next, there are several diversification theories, including:

a. Random Diversification

This theory describes the steps of investors in making random investments in different stocks and the expectation of variations in returns to reduce the risk of their portfolio. In the thinking of random diversification investors, they assume that they will benefit from reduced risk by adding types of assets to the portfolio, but in reality the concept of random diversification will only make the benefits of risk confinement decrease, because each asset has its own marginal risk.

b. Markowitz Diversification

This theory was created by Henry Markowitz (1950). Markowitz's popular saying to mean diversification is don't put all your eggs in one basket, if it is interpreted in the scope of investment, don't invest all your resources in one type of asset. The benefits of doing diversification occur when the asset returns are not correlated with each other (independent). Therefore, to calculate portfolio risk, one must also consider the correlation between the returns of an asset with other assets. In 1964 and 1965 William Sharpe (1964) and John Lintner (1965) introduced the CAPM theory that can be used to evaluate an asset. The CAPM theory begins with the assumption that the capital market is 
a market that is close to perfect competition, so prices are formed through available information and obtained by market players. This gives the hypothesis that the market price is an efficient price. CAPM theory is a model that calculates the relationship of potential returns with existing risks, where the risk variable used is the potential return of market prices or is called systematic risk. The expected rate of return can be calculated using the CAPM model with the formula $i=R f+i[\bar{R} m-R f]$

There are several assumptions in the CAPM model, namely:

a. It is assumed that there are free of cost transactions on both buy and sell activities. In fact, the cost will always be there, so it can reduce the return on investment.

b. It is assumed that shares can be released in the smallest unit (1), so that investors can transact these units, even though in reality this assumption cannot be applied, because the minimum purchase unit is 1 lot (100 shares).

c. Free of Income Tax both from dividends and capital gains. But in reality, at least in Indonesia, both dividends and capital gains are subject to income tax (income tax) at different rates, dividends have a final tax rate of $10 \%$ of the value of dividends distributed, while capital gains have a final tax rate of $0.1 \%$ of the value of the sale of shares.

d. No investor is able to influence the rise and fall of the price of a stock. This assumption is based on the capital market is a perfectly competitive market, the price reflected is the effect of market sentiment as a result of the information that has been received by all investors so that the price is assumed to be formed due to the available information. However, in the capital market industry, it appears that market players in Indonesia are not yet fully characterized, speculators, and not evenly distributed across all levels of society so that investment behavior has the potential to be controlled by certain market players which can affect the level of stock prices in the market.

Research by Kendall (1953), concluded that stock prices make unpredictable patterns because they move randomly. According to him, the stock market is heavily influenced by market psychology and doesn't seem to follow the rules.

\section{Efficient Market Hypothesis (EMH) Theory}

An information is said to be relevant if the information is able to influence the perception of policy makers from the absorption of the information. It's the same when someone wants to buy something in a traditional market, before buying it can be ascertained that the person knows the market price of the goods to be purchased in the market, so that there is no over-price and causes losses. In the capital market, most investors use financial statements as the basis for conducting their investment and business activities.

An important factor in analyzing an efficient market is the correlation between information and the security. Professor Eugene Fama (1970) presented at least 3 
examples of market efficiency based on information, namely: weak form, semistrong form, and strong form.

\section{METHOD}

In this study, the statistical method Structural Equation Modeling (SEM) is used which will be run using the AMOS 22.00 program and will go through testing stages, namely: data normality test (univariate \& multivariate normality), multicollinearity and singularity test, convergent validity test (model fit), goodness of fit (GFI) test, to testing research hypotheses using the t-value in the regression weights for direct effects, and using the p-value in the Sobel test for indirect effects.

This study uses a population that is a Pension Fund that has been registered with the Financial Services Authority (OJK) in the 2016-2019 period. Purposive sampling is the method used in sampling in this study. Initially, the number of samples was initially set at 400 observation samples, but due to the selection process for outlier data seen through Mahalanobis Distance (d2) until the sample can be declared fit, causing the number of samples to shrink to 136 observation samples. The information obtained by the researcher from the OJK is in the form of Pension Fund financial statements, portfolio \& individual ROI, and portfolio composition. In this study, the cash flow at the end of the pension fund period becomes a proxy fund cashflow, and the total investment outside of cash becomes a proxy fund size.

\section{RESULTS AND DISCUSSION}

\section{Effect of Fund Cash Flow on Diversification}

Fund Cashflow or net cash flow which shows growth in fund assets, in this study did not have a significant impact on diversification. This is due to the existence of regulations from the regulator that limit the placement of investments made by Pension Funds in certain sectors. This is in line with the research conducted by M. Ardiansyah and Farah Margaretha Leon (2018) who conducted research on the factors that affect Portfolio Diversification and concluded that income and cash flow had no effect on Portfolio Diversification.

\section{Effect of Timing Ability on Diversification}

The ability of investment managers to take the right policies to buy or sell certain securities to form a portfolio of assets at the right time does not have a significant impact on diversification. This means that pension fund managers are not able to make transactions in buying and selling securities at the right time because of the limited space for pension fund managers to follow the investment rules issued by the regulator. This is also in line with the Theory of reasoned action developed by Fishbein and Ajzen (1975) which says that the behavior of every decision maker has the intention to do so and is related to activities carried out on their own volition (volitional) based on a reasonable way, consideration information and rules and the implications of their every action. 


\section{Effect of Selection Ability on Diversification}

The ability to select certain securities to form a portfolio, has a significant effect on portfolio diversification. This means that pension fund managers are able to exercise selection ability because it is required by the regulator through POJK 3/2015 which requires each Pension Fund to have a maximum investment limit in each sector for diversification purposes.

\section{Effect of Fund Size on Diversification}

The amount of funds managed by the Pension Fund has a significant effect on diversification. This gives a meaning that is in line with the theory which says that the larger the funds managed will facilitate the spread of investments made in order to avoid a single source of risk.

\section{Effect of Fund Cashflow on Portfolio Performance}

This research is not enough to give a significant effect on portfolio performance. This is due to the existence of regulations from the regulator that limit the placement of investments made by Pension Funds in certain sectors so that it affects the performance of the portfolio itself.

\section{Effect of Timing Ability on Portfolio Performance}

This study has a significant effect on portfolio performance. This shows that the Pension Fund manager during the research period has a strong timing ability because of the support from the regulator's rules with the principle of prudence.

\section{Effect of Selection Ability on Portfolio Performance}

This study has no significant effect on portfolio performance. This shows that the Pension Fund manager during the research period did not have a strong selection ability because of the regulatory rules that limit the investment space for the pension fund manager.

\section{Effect of Fund Size on Portfolio Performance}

This research is not enough to give a significant effect on portfolio performance. This is due to the existence of regulations from the regulator that limit the placement of investments made by Pension Funds in certain sectors so that it affects the performance of the portfolio itself.

\section{Effect of Diversification on Portfolio Performance}

This research is not enough to give a significant effect on portfolio performance. This is due to the existence of regulations from the regulator that limit the placement of investments made by Pension Funds in certain sectors so that it affects the performance of the portfolio itself. 
10. Effect of Fund Cashflow on Portfolio Performance with Diversification as an Intervening Variable

Fund Cashflow mediated by Diversification does not have a significant effect on portfolio performance. This shows that the diversification carried out by Pension Fund managers has limitations, so it cannot mediate Fund Cashflow on portfolio performance.

\section{The Effect of Timing Ability on Portfolio Performance with Diversification} as an Intervening Variable

Timing Ability mediated by Diversification does not have a significant effect on portfolio performance. This shows that the diversification carried out by Pension Fund managers has limitations, so it cannot mediate Timing Ability on portfolio performance.

\section{Effect of Selection Ability on Portfolio Performance with Diversification as an Intervening Variable}

Selection Ability mediated by Diversification does not have a significant effect on portfolio performance. This shows that the diversification carried out by Pension Fund managers has limitations, so it cannot mediate Selection Ability on portfolio performance.

\section{Effect of Fund Size on Portfolio Performance with Diversification as an Intervening Variable}

Fund Size mediated by diversification does not have a significant effect on portfolio performance. This shows that the diversification carried out by Pension Fund managers has limitations, so it cannot mediate Fund Size on portfolio performance.

\section{E. CONCLUSION}

Fund Cashflow, Timing Ability and Fund Size have a positive but not significant effect on diversification, indicating that the asset allocation strategy in the study period has not been able to provide a positive impact on portfolio diversification. This can be made possible because of the new regulation from OJK as the regulator which limits the scope of Pension Fund investment.

Selection Ability has a positive and significant effect on Diversification, indicating that Pension Fund managers have good ability in choosing asset allocation strategies to anticipate risks that may occur during this research period.

Fund Cashflow, Selection Ability, Fund Size and Diversification have a positive but not significant effect on Portfolio Performance, indicating that Pension Fund managers have not been able to maximize their asset allocation strategy to improve portfolio performance in this research period. This is again possible due to the limitation of the scope of the Pension Fund as a result of the issuance of regulations from the OJK as the regulator. 
Timing Ability has a positive and significant effect on Portfolio Performance, indicating that Pension Fund managers can maximize strategies when to enter and exit their investment activities to improve portfolio performance in this research period. Diversification has not been able to mediate Fund Cashflow, Timing Ability, Selection Ability and Fund Size on Portfolio Performance, indicating that Pension Fund management in this research period cannot maximize Diversification as a mediating variable for asset allocation strategies to improve the Portfolio Performance.

\section{REFERENCES}

1. Agung, J. R. D. M. S., \& Wirasedana, I. W. P. (2014). Analisis Kinerja Reksadana Saham di Indonesia. E-Jurnal Akuntansi Universitas Udayana, 7(1), 250-265.

2. Andini, N. W. L., \& Wirawati, N. G. P. (2014). Pengaruh cash flow pada kinerja keuangan dan implikasinya pada nilai perusahaan manufaktur. E-Jurnal Akuntansi Universitas Udayana, 7(1), 107-121.

3. Aisjah, S. (2012). Strategi Diversifikasi Korporat: Penciptaan Nilai Perusahaan. Malang: UB Press.

4. Ardila, I. (2019). Teori dan Konsep Invetasi: Investa Mandiri. Yogyakarta: Investa Mandiri.

5. Eduardus, T. (2001). Analisis Investasi dan Manajemen Portofolio. Yogyakarta: BPFE.

6. Ferdinand, A. (2006). Structural Equation Modelling dalam Penelitian Manajemen. Semarang: Badan Penerbit Universitas Diponogoro.

7. Government Regulation of the Republic of Indonesia Number 76 of 1992 concerning Employer Pension Funds.

8. Government Regulation of the Republic of Indonesia Number 77 of 1992 concerning Financial Institution Pension Funds.

9. Handini, S., \& Astawinetu, E. D. (2020). Teori Portofolio dan Pasar Modal Indonesia. Surabaya: Scopindo Media Pustaka.

10. Haryono, S. (2016). Metode SEM untuk Penelitian Manajemen dengan AMOS LISREL PLS. Bekasi: Intermedia Personalia Utama.

11. Hermawan, D., \& Wiagustini, N. L. P. (2016). Pengaruh Inflasi, Suku Bunga, Ukuran Reksa Dana dan Umur Reksa Dana terhadap Kinerja Reksa Dana. Bali: Fakultas Ekonomi dan Bisnis, Universitas Udayana.

12. Hidayat, A. (2012). Penjelasan Lengkap Berbagai Jenis Variabel Penelitian. Retrieved from https://www.statistikian.com/2012/10/variabel-penelitian.html

13. Kubuanto. (2002). Hubungan Resiko Perusahan serta Pengaruhnya terhadap Diversifikasi dan Portofolio Saham. Jakarta: Fakultas Ekonomi, Universitas Bina Nusantara.

14. Law of the Republic of Indonesia Number 11 of 1992 concerning Pension Funds.

15. Mustofa, F. S., \& Kusumawardhani, A. (2016). Pengaruh Stock Selection Ability dan Market Timing Ability terhadap Kinerja Reksa Dana Syariah Saham menggunakan Model Conditional dan Unconditional. Semarang: Fakultas Ekonomika dan Bisnis, Universitas Diponegoro. 
16. Nursyabani, P. A., \& Mahfud. (2016). Analisis Pengaruh Cash Flow, Fund Size, Family Size, Expense Ratio, Stock Selection Ability dan Load Fee terhadap Kinerja Reksa Dana Saham. Semarang: Fakultas Ekonomika dan Bisnis, Universitas Diponegoro.

17. Paramitha, A. S. P. P., \& Purnawati, N. K. (2017). Pengaruh Kinerja Manajer Investasi dan Kebijakan Alokasi Aset terhadap Kinerja Reksa Dana Saham di Indonesia (Doctoral dissertation, Udayana University).

18. Putri, C. H. M., \& Haryanto, A. M. (2014). Analisis Pengaruh Market Timing Ability, Stock Selection Skill, Expense Ratio Dan Tingkat Risiko Terhadap Kinerja Reksa Dana Saham (Studi Pada Reksa Dana Saham Jenis KIK Periode 2009-2013) (Doctoral dissertation, Fakultas Ekonomika dan Bisnis).

19. Rahardi, A. N. (2013). Analisis Komparasi Pengukuran Kinerja Reksa Dana Menggunakan Metode Sharpe, Treynor dan M2. Skripsi dipublikasikan Program Studi Manajemen, Universitas Diponegoro.

20. Regulation of the Financial Services Authority of the Republic of Indonesia Number 3 of 2015 concerning Pension Fund Investment.

21. Regulation of the Financial Services Authority of the Republic of Indonesia Number 01 of 2016 concerning Investment in Government Securities for Non-Bank Financial Services Institutions.

22. Regulation of the Financial Services Authority of the Republic of Indonesia Number 13 of 2016 concerning Procedures for Application for Legalization of the Establishment of Employer Pension Funds and Ratification of Amendments to Pension Fund Regulations of Employer Pension Funds.

23. Regulation of the Financial Services Authority of the Republic of Indonesia Number 14 of 2016 concerning Procedures for Application for Legalization of the Establishment of a Financial Institution Pension Fund and Amendment to the Regulation of the Pension Fund of a Financial Institution Pension Fund.

24. Regulation of the Minister of Finance of the Republic of Indonesia Number 199 of 2008 concerning Pension Fund Investment.

25. Regulation of the Minister of Finance of the Republic of Indonesia Number 19 of 2012 concerning Amendments to Regulation of the Minister of Finance Number 199 of 2008 concerning Investment in Pension Funds.

26. Riadi, M. (2020). Pengertian dan Jenis-jenis Variabel Penelitian. Retrieved from https://www.kajianpustaka.com/2020/09/pengertian-dan-jenis-variabelpenelitian.html

27. Ropikoh. (2006). Analisis Ukuran Perusahaan dan Diversifikasi. Jakarta.

28. Sudana, I. M., \& Janiarti, M. (2000). PengaruhUkuran Portfolio terhadap Tingkat Diversifikasi Saham: Perbandinganantara Portfolio Saham Satu Industri dengan Portfolio Saham Beragam Industri di BEJ. Majalah Ekonomi Tahun X, (1), 28-42.

29. Sugiyono. (2007). Metode Penelitian Administrasi. Bandung: Alfabeta.

30. Sumiati \& Indrawati, N. K. (2019). Manajemen Keuangan Perusahaan. Malang: UB Press.

31. Syahid, N., \& Arfinto, E. D. (2015). Analisis Pengaruh Stock Selection Skill, Market Timing Ability, Fund Longevity, Fund Cash Flow dan Fund Size Terhadap Kinerja Reksa 
Dana (Studi Kasus: Reksadana Saham Periode Tahun 2010-2014). (Doctoral dissertation, Fakultas Ekonomika dan Bisnis).

32. Waluyo, M. (2016). Mudah Cepat Tepat Penggunaan Tools Amos dalam Aplikasi (SEM). Surabaya: UPN Veteran Jawa Timur.

33. Yanti, N. I. (2017). Pengaruh Kebijakan Alokasi Aset, Pemilihan Saham dan Tingkat Risiko Terhadap Kinerja Reksadana Campuran Periode 2010-201. Jurnal Ilmu Manajemen (JIM), 5(4).

34. Zacharias, J. A. (2020). Teori Portofolio Investasi. Klaten: Lakeisha. 